\title{
MEMAKNAI BAHASA DAN MEMBAHASAKAN MAKNA \\ DALAM PENULISAN BUKU HINDU
}

\author{
I Wayan Sukarma \\ Pascasarjana Universitas Hindu Indonesia
}

\begin{abstract}
ABSTRAK
Agama membuka dan menyediakan wawasan tentang kebenaran iman yang absolut. Dibandingkan dengan kebenaran filsafat yang spekulatif hipotetis, tampaklah kedua macam kebenaran itu paradoks. Bahasa agama yang religius terkesan menguasai pikiran yang rasional, sedangkan bahasa filsafat yang kritis terkesan menguasai pengalaman yang empiris. Padahal, jika dilihat dari kesepasangan dan kesetimbangan, maka agama adalah sisi praktis dari filsafat dan filsafat adalah sisi rasional dari agama. Memadukan kedua bahasa itulah ditawarkan pendekatan 'teman ngobrol'. Perlakuan bahasa semacam ini dimaksudkan hendak mengurangi 'beban penulis' untuk mencapai makna filosofis, tanpa meninggalkan makna agamis. Sederhananya, penulis buku Hindu disarankan memandang teks agama sebagai teman ngobrol agar lebih mudah memahami dan mengapresiasikannya dengan bahasa jurnalistik.
\end{abstract}

\section{Kata Kunci: Memaknai Bahasa, Membahasakan Makna, dan Penulisan Buku Hindu.}

\section{PENDAHULUAN}

Kehidupan hanyalah ngobrol. Kodrat sebagai individu yang sosial membuat kita tidak nyaman sendirian. Dalam keseharian kita ngobrol bersama teman-teman. Teman (bersama) itu kita sebut saja teman ngobrol. Merekalah pasangan hidup - dalam dunia kehidupan - entah berkaitan dengan kebutuhkan, keperluan, ataupun kepentingkan. Merekalah "teman berbagi tanpa membagi", sebagaimana sifat pikiran dan kebiasaannya. Merekalah yang mengucapkan kata "Ya", berarti "Ya", dan bermakna "Ya" dengan kepala mengangguk berkalikali. Tegasnya, istilah "ngobrol" memiliki asosisiasi dengan aktivitas mengendorkan ketegangan syaraf sehingga memungkinkan lahirnya inspirasi segar tentang kehinduan.
Frasa "ngobrol bersama", "teman ngobrol", dan "pasangan hidup" saya tulis cetak miring karena mencerminkan kedekatan, baik pikiran dan perasaan maupun persepsi dan gagasan. Lewat ngobrol kita berbagi pesan, bukan hanya secara lisan, bahkan dengan tulisan, bahasa tubuh, gaya, penampilan, dan alat bantu. Kita bersama-sama memasuki dan berada dalam suatu obrolan dengan melibatkan kondisi pisik, situasi mental, dan suasana hati. Hubungan yang erat memang memudahkan membangun makna yang sama atas pesan yang sedang kita bagi, karena itu lebih mudah saling memahami. Di sinilah letak pondasi komunikasi efektif dan padanya tergantung keberhasilan proses komunikasi. Keberhasilan komunikasi Hindu, juga tergantung pada efektivitas penggunaan sistem simbol linguistik karena Liliweri (2002) mengatakan, 
komunikasi dapat dipahami sebagai aktivitas simbolik. Artinya, efektivitas dan keberhasilan komunikasi tulisan Hindu terikat dan tergantung pada upaya membahasakan makna dan memaknai bahasa Hindu.

Komunikasi model itu penting saya ajukan karena selama ini kata "Hindu" terlalu banyak dibebani dengan pengertian yang rumit, baik dalam hal interpretasi filsafat maupun sosialhistoris. Dari sisi filsafat misalnya, kata "Hindu" memiliki pengertian yang tidak seragam, setidak-tidaknya dalam pandangan Radhakrishnan dan koleganya pemikir India kontemporer P.T Raju. Begitu pun secara sosialhistoris kata "Hindu" dimaknai lebih multi-interpretatif, bahkan cenderung etnosentris dan fasis. Untuk mengurangi beban itulah pendekatan "teman ngobrol" tentang kehinduan relevan saya ajukan dalam pertemuan ini. Konkretnya, "bahasa jurnalistik" karena sifatnya yang cair, sederhana, menyegarkan, dan mengundang diskusi - menjadi alternatif paling dekat dalam membahasakan makna dan memaknai bahasa Hindu.

\section{PEMBAHASAN}

\subsection{Memaknai Bahasa Hindu}

\section{Bahasa menjalin kehidupan} dengan suatu tatanan-dunia yang mengikat sekaligus menyatukan manusia menjadi masyarakat. Pandangan ilmu-ilmu sosial itu menegaskan, bahasa adalah masyarakat dan masyarakat adalah bahasa. Malahan Sumarna (2008:233) mengatakan, bahasa membuat manusia mampu membangun komunikasi dengan dirinya sendiri dan dunia kehidupan. Bahasa membentuk pikiran, perasaan, dan kencenderungan bertindak karena bahasa mempengarui kesadaran, gagasan, dan aktivitas manusia. Manusia berkesadaran karena ia tahu bahwa ia mengetahui sesuatu, sebagaimana dibuktikan dalam berpikir dan berkomunikasi. Berpikir adalah aktivitas berkata-kata dalam hati sendiri dan berkomunikasi adalah berkata-kata antarsubjek. Mengingat kedua kegiatan ini merupakan tindak tutur dengan menekankan pada penggunaan kata-kata sehingga kegiatan semacam ini tidak dimungkinkan tanpa bahasa.

Dengan bahasa, manusia dapat saling memahami dan mewujudkan pengertian di antara sesamanya. Kesalingpengertian dan pemahaman inilah yang dimaksudkan dengan kesadaran dan di dalamnya bahasa menjadi alat dan wujud kesadaran itu sendiri. Ketika bahasa diterima menjadi wujud kesadaran kolektif masyarakat manusia, maka manusia sudah menciptakan wacana di dalam dunianya (Pitana, 2017:3). Dalam dunia kehidupan setidaknya, Salam (1997:136--137) mengemukakan bahwa bahasa mempunyai dua fungsi utama, yaitu komunikatif dan kohesif. Fungsi kohesif mengintegrasikan berbagai suku - yang memiliki bahasa-bahasa yang telah matang fungsi komunikatifnya ke dalam satu bangsa dengan satu bahasa. Fungsi komunikatif mencakup bahasa sebagai alat komunikasi untuk menyampaikan pesan yang berkonotasi pikiran (kognitif), perasaan (emotif), dan sikap (afektif).

Perkembangan bahasa sesungguhnya mencerminkan pertumbuhan ketiga fungsi komunikasi bahasa tersebut. Misalnya, kemajuan pada bidang seni berkaitan erat dengan perkembangan bahasa dalam fungsi perasaan dan sikap, sedangkan kemajuan pada bidang ilmu berkaitan dengan perkembangan bahasa dalam 
fungsi penalaran. Meskipun ketiga fungsi bahasa itu tidak mutlak begitu, tetapi setidaknya kategori itu dapat menjadi pijakan untuk memahami ragam bahasa berkaitan dengan aspek kehidupan dan bidang keilmuan. Kita memang membutuhkan fungsi bahasa untuk membentuk pengertian dan pemahaman yang lebih jelas tentang kata-kata yang kita gunakan dalam komunikasi, apalagi dalam bentuk tulisan. Tanpa kejelasan fungsi bahasa, sebuah kata akan bias dan mengambangkan pesan menjadi tanpa makna. Misalnya, kata "Hindu". Kata tersebut begitu abstrak, karena itu kita tidak dapat langsung mengerti dan memahami ketika seseorang mengucapkannya. Seperti ungkapan, "I Love Hindu". Kita tidak mudah memahaminya karena kata "Hindu" dalam ungkapan tersebut tidak jelas merujuk dan menunjuk suatu objek (indrawi). Entah Hindu sebagai barang sesuatu, suatu tempat, suatu pemikiran, suatu kepercayaan, ataupun suatu kebudayaan.

Kata "Hindu" memang abstrak, tetapi 'bertuah'. Kata tersebut sudah begitu luas dan mendalam mempengaruhi pikiran, perasaan, dan sikap insan kampus dan memenuhi relung batin pemeluk agama Hindu. Misalnya, pertemuan kita ini menggunakan frasa, "Penulis Kampus Hindu". Kemudian, dapat saya bayangkan: 'penulis yang berasal dari kampus yang berbasis (agama) Hindu'. Kata "agama" saya tulis dalam tanda kurung hanya untuk menunda maknanya karena - pengalaman saya menunjukkan - dalam Kampus Hindu kita tidak melulu belajar agama Hindu, tetapi hampir seluruh jenis pengetahuan kehinduan. Apabila mengacu pada pandangan Tafsir (2006) tentang jenis pengetahuan, maka kata "Hindu" dapat dimaknai dan dipahami sebagai pengetahuan biasa, pengetahuan sains, pengetahuan filsafat, pengetahuan etis, pengetahuan estetis, pengetahuan mistis, ataupun kebudayaan. Hindu mencakup keseluruhan aspek kehidupan dan jenis keilmuan untuk menangani kehidupan. Kecuali pengetahuan biasa, semua jenis pengetahuan lainnya yang saya sebutkan itu menimbulkan pertanyaan yang tidak berkesudahan. Sebagian jawaban dari pertanyaan rasional-yang-empiris, berupa hasil penelitian barangkali sudah memenuhi perpustakaan kampus-kampus Hindu. Akan tetapi, lebih banyak lagi pertanyaan kehinduan yang tidak (barangkali belum) tersingkap dan terungkap menjadi pengetahuan benar, kebenaran.

Padahal setiap jenis tradisi keilmuan mempunyai ragam bahasa beserta fungsinya untuk menyingkap dan mengungkap makna yang tersimpan dan tersembunyi di balik kata "Hindu" dan "Kehinduan" - baik gejala, fenomena, teks, maupun keseharian. Hanya saja penggunaan ragam bahasa ilmiah dalam kegiatan kampus lazimnya menimbulkan kesan eksklusif, karena itu dijuluki bahasa kampus, bahasa akademis. Bahasa kampus yang hanya dipahami insan kampus, seperti skripsi, tesis, disertasi, dan artikel ilmiah lainnya tanpa kita sadari menyekat komunikasi kampus dengan masyarakat. Apalagi keterbatasan interpretasi dan pemahaman atas ragam bahasa Hindu tidak dapat dihindari menimbulkan diskusi dan debat yang kontra produktif bagi perkembangan Hindu itu sendiri. Misalnya, perdebatan antara bahasa filsafat Hindu yang argumentatif (hanya rasional) dan bahasa sains Hindu yang ilmiah (rasional dan empiris) dengan bahasa agama Hindu yang mistik (sraddha- 
bhakti) dapat menimbulkan kesangsian, baik sebagian maupun keseluruhan atas kepercayaan Hindu.

Memadukan bahasa pikiran yang akademis (dan filosofis) dengan bahasa tindakan yang empiris barangkali sebagian dari tugas bahasa sains dan bahasa etis dengan mengikuti kaidah-kaidah bahasa estetis Hindu. Misalnya, krama banjar di Bali melaksanakan pembelajaran seni budaya melalui sekaa-sekaa kesenian untuk menjalankan kewajiban agama dan mengembangkan kebudayaan. Model pembelajaran seperti itu menampakkan agama Hindu begitu menyatu dengan kebudayaan menjadi tradisi. Pewarisan nilai-nilai seni budaya itu merupakan fenomena bahasa keseharian Hindu yang terformulasikan dari bahasa (pengetahuan) biasa dalam kehidupan sehari-hari. Artinya, kalau bahasa akademis menjadi persyaratan karya ilmiah, barangkali bahasa buku tidak wajib memenuhi kebakuan dan kebekuan bahasa ilmiah. Untuk mempersempit jurang antara bahasa akademis dan bahasa keseharian itulah saya menawarkan bahasa jurnalistik dalam penulisan buku Hindu.

\subsection{Membahasakan Makna Hindu}

Bahasa jurnalistik saya tawarkan dengan pertimbangan (yang hanya berdasarkan dugaan), perkembangan Hinduisme dari struti hingga smerthi merupakan hasil interpretasi dan pemahaman berulang-ulang secara berkelanjutan sepanjang masa berdasarkan bahasa Hindu yang beragam. Hindu sebagai agama pun mempunyai ragam bahasa agama. Bahasa agama berbeda dengan bahasa ilmiah yang kita pergunakan dalam kegiatan ilmiah dan bahasa biasa yang kita pergunakan dalam keseharian. Berkaitan dengan bahasa agama,
Bakhtiar (2016:175) memberikannya dua macam pengertian mendasar, yaitu bahasa agama sebagai kalam Ilahi (kitab suci) serta sebagai ungkapan dan perilaku keagamaan. Bahasa agama menggunakan gaya deksriptif dan preskriptif. Gaya deskriptif memungkinkan pembaca berpartisipasi untuk menafsirkan dan mengembangkan makna yang lebih luas dan mendalam. Gaya preskriptif melibatkan struktur makna yang bersifat imperatif dan persuasif, yaitu cenderung memerintah. Selain itu, juga bahasa menimbulkan dorongan melakukan transformasi (Sumarna, 2008:236), karena itu bahasa agama memungkinkan umat agama melakukan transformasi ajaran agamanya menjadi beragam makna. Untuk menyingkap dan mengungkap makna agama agar lebih mudah dipahami dan dipraktikkan mengingatkan kita akan kesederhanaan dan kepraktisan bahasa jurnalistik.

Bahasa jurnalistik saya maksudkan, serupa dengan pandangan Sumadiria (2006:48) memiliki kaidah yang berbeda dengan bahasa ilmiah dan ragam bahasa lainnya, tetapi menggunakan kosakata, struktur sintaksis, dan wacana sesuai dengan kaidah bahasa Indonesia. Kaidah bahasa jurnalistik, seperti diungkapkan Romli (2005:25) menggunakan kata-kata populer yang akrab dengan kehidupan sehari-hari serta susunan kalimat yang tidak kaku dan formal. Bahasa jurnalistik ditandai dengan karakteristiknya yang sederhana, singkat, ringkas, padat, lugas, jelas, dan jernih. Seperti susunan kalimat yang mudah dimengerti, langsung pada pokok pembahasan, sarat informasi, tidak ambigu, tidak baur, dan tidak menyembunyikan makna. Karakteristik lain yang membuatnya menarik untuk menyampaikan gagasan kehinduan

\section{VIDYA WERTTA}

Vol. 1 Nomor 2, Oktober 2018 
dalam bentuk tulisan karena bahasa jurnalistik mampu membangkitkan minat pembaca, tidak mengenal derajat/tingkatan, diksi yang karib dengan pembaca, tidak bertentangan dengan akal-sehat, serta menggunakan bahasa baku, benar, baik, dan bagus. Karakteristik ini akan lebih produktif dengan dukungan kesadaran penulis bahwa menulis untuk mengungkapkan pesan melalui susunan kalimat aktif dan kata kerja konkret sehingga menumbuhkan penerimaan yang intim semacam obrolan.

Menyampaikan ide-ide dan gagasan kehinduan dalam bentuk tulisan menggunakan bahasa jurnalistik sehingga menjadi 'teman ngobrol' (bagi pembaca) memang tidak mudah karena ajaran agama Hindu lebih banyak tersedia dalam bentuk kesusasteraan yang begitu sublim. Membahasakan makna kesusastraan agama Hindu membutuhkan ketekunan dan kesabaran dalam pergulatan kode, tanda, dan simbol secara berkesinambungan. Bersyukur banyak penulis Hindu menunjukkan runtutan membacanya, seperti diterangkan Gunadha (2012), kitab Sruti sebagai sumber hukum kehidupan tertinggi sudah terjabarkan ke dalam kitab Smerti, Sila, Acara, dan Atmanastuti. Penjabaran seperti tersebut, juga diterangkan dalam Manawadharmasastra, II.6 berikut" Seluruh pustaka suci Weda (Sruti dan Smerti) merupakan sumber pertama dari dharma. Kemudian adat istiadat, setelah itu tingkah laku yang terpuji dari orangorang bijak yang mendalami ajaran suci Weda (sila), juga tata cara kehidupan orang suci (acara), dan akhirnya kepuasan pribadi (atmanastuti)". Artinya, makna Hindu dapat dipahami dan ditafsirkan berdasarkan penjabaran itu dengan mengikuti tiga kerangka agama Hindu.

\section{PENUTUP}

Bahasa itu medium tanpa batas. Barangkali memuat pamahaman yang melampaui pengertian manusia. Sederhananya, memahami bahasa memberikan kemungkinan untuk memahami pemahaman manusia. Manusia menciptakan dunia pemahaman melalui bahasa dan dunia pemahaman membentuk kebiasaan manusia. Artinya, bahasa mempunyai daya rekayasa terhadap perilaku manusia. Malahan dalam dunia kehidupan berlaku hukum: "membahasakan atau dibahasakan". Bahasa menjadi media penguasaan ketika pemakainya menggunakan sifat imperatif dan persuasif bahasa untuk memaksakan pandangannya. Pada kedua sifat bahasa inilah titik sentral siar agama, karena itu Penulis Kampus Hindu saya sarankan menggunakannya dalam ragam bahasa jurnalistik.

\section{Daftar Pustaka}

Adib, H. Mohammad. 2014. Filsafat Ilmu: Ontologi, Efistemologi, Aksiologi, dan Logika Ilmu Pengetahuan. Yogyakarta: Pustaka Pelajar.

Bakhtiar, Amsal. 2016. Filsafat Ilmu. Jakarta: RajaGrafindo Persada.

Liliweri, Alo. 2002. Makna Komunikasi Dalam Komunikasi Antarbudaya (Cetakan I). Yogyakarta: LKiS.

Pitana, Titis Srimuda. 2017. "Diskursus Omah Sebagai Ekspresi Keindahan Budaya Jawa", Makalah. Dipresentasikan dalam Seminar

Nasional 
diselenggarakan Sekolah Tinggi Hindu Dharma (STHD) Klaten bekerjasama dengan Sruti Budaya Surakarta dengan tema "Estetika Lokal Untuk Mewujudkan Unggulan Daerah", tanggal 6 November 2017 di Hotel Dana Surakarta.

Romli, Asep Syamsul M. 2005. Bahasa Media: Panduan Praktis Bahasa Junarlistik. Bandung: Batik Press.

Salam, H Burhanuddin. 1997. Loagika Materiil: Filsafat Ilmu Pengetahuan. Jakarta: Reneka Cipta.

Sudharta, Tjok. Rai dan Gde Pudja MA. 2000. Manawa Dharmasastra:
Kompedium Hukum Hindu. Jakarta: Balai Pustaka.

Sumadiria, A.S Haris. 2006. Bahasa Jurnalistik. Bandung: Rosdakarya.

Sumarna, Cecep. 2008. Filsafat Ilmu. Bandung: Mulia Press.

Tafsir, Ahmad. 2006. Filsafat Ilmu: Mengurai Ontologi, Epistemologi, dan Aksiologi Pengetahuan. Bandung: Remaja Rosdakarya.

Wilkes, Keith. 1982. Agama dan Ilmu Pengetahuan. Jakarta: Sinar Harapan. 